\title{
Concise and Efficient Total Syntheses of Virenamides A and D
}

Haifeng Gan, Zhengbang Chen, Zheng Fang, Kai Guo*

College of Biotechnology and Pharmaceutical Engineering, Nanjing University of Technology, Nanjing 211816, China,

Email: eghf_005@sina.com

College of Biotechnology and Pharmaceutical Engineering, Nanjing University of Technology, Nanjing 211816, China,

Email: zhengbangchen@163.com

School of Pharmaceutical Sciences, Nanjing University of Technology, Nanjing 211816, China,

Email: fzcpu@163.com

College of Biotechnology and Pharmaceutical Engineering, Nanjing University of Technology, Nanjing 211816, China,

\section{ABSTRACT}

Email: kaiguo@njut.edu.cn

Concise total syntheses of linear thiazole-containing peptides virenamides A (1) and D (4), isolated from Australian ascidian Diplosoma virens have been accomplished from Boc-L-valine (6) in 7 steps. A cyclization between thioamide and bromoacetaldehyde was applied to form thiazole ring as a key step.

\section{Indexing terms/Keywords}

Total syntheses; Virenamide; Ascidian Diplosoma virens; Thiazole

\section{Academic Discipline And Sub-Disciplines}

Organic chemistry

\section{SUBJECT CLASSIFICATION}

Heterocyclic compounds

\section{TYPE (METHOD/APPROACH)}

Synthesis and experimental study

\section{Council for Innovative Research}

\author{
Peer Review Research Publishing System
}

\section{Journal: Journal of Advances in Chemistry}

\author{
Vol. 4, No. 3 \\ editor@cirworld.com \\ www.cirworld.com, member.cirworld.com
}




\section{INTRODUCTION}

Marine natural products are a rich source of novel peptides, many of which show high levels of biological activity [1-3]. For example, the thiazole-containing cyclic peptide largazole exhibits extremely potent antiproliferative activity against a number of cancer cell-lines including MDA-MB-231 mammary cells ( $\left.\mathrm{Gl}_{50} 7.7 \mathrm{nM}\right)$, U2OS fibroblastic osteosarcoma cells $\left(\mathrm{Gl}_{50} 55 \mathrm{nM}\right), \mathrm{HT} 29$ colon cells $\left(\mathrm{Gl}_{50} 12 \mathrm{nM}\right)$, and IMR-32 neuroblastoma cells $\left(\mathrm{Gl}_{50} 16 \mathrm{nM}\right)$ and linear thiazole-containing peptide dolastatin 10 is one of the most potent antineoplastic agents [4-5]. Over a decade ago, Bowden et. al isolated five cytotoxic linear peptides virenamides A-E (1-5) from Australian ascidian Diplosoma virens and assigned their structures by extensive NMR experiments [6-7]. In 1999, Moody et. al had reported a stereoselective synthesis of virenamide B (2) in which an elegant diastereoselective addition of 2-lithiothiazole to oxime ether was applied to construct the thiazole ring in excellent yield and diastereomeric excess [8]. For a long term concern, we initiated the total synthesis of virenamides in order to investigate the potential bioactivity of the derivatives. Herein, we report the concise efficient total syntheses of virenamides $A(\mathbf{1})$ and $D(4)$ from accessible starting material Boc-L-valine (6), which would provide enough product for further biological studies.<smiles>CC(C)=CCN(CC=C(C)C)[C@@H](Cc1ccccc1)C(=O)N[C@H](C(=O)N[C@H](c1nccs1)C(C)C)C(C)C</smiles>

virenamide $A$ (1)<smiles>C=CC(C)(C)N[C@@H](Cc1ccccc1)C(=O)N[C@@H](Cc1ccccc1)C(=O)N[C@H](c1nccs1)C(C)C</smiles>

virenamide B (2)

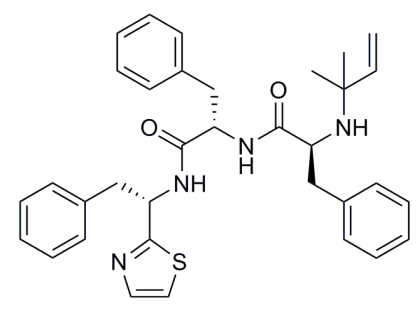

virenamide C (3)<smiles>CC(C)=CCN[C@@H](Cc1ccccc1)C(=O)N[C@H](C(=O)N[C@H](c1nccs1)C(C)C)C(C)C</smiles>

virenamide $D(4)$<smiles>CC(C)[C@H](NC(=O)/C=C/c1ccccc1)N(NC(=O)/C=C/c1nccs1)C(C)C</smiles>

virenamide $E(5)$

Fig. 1 Chemical structures of virenamides A-E (1-5)

Our initial retrosynthetic analysis of 1 and 4 is outlined in Scheme 1. We envisaged that the thiazole ring of 1 and 4 could be constructed through a cyclization between thioamide 9 and bromoacetaldehyde 10. Thioamide 9 in turn could be obtained from a cheap starting material Boc-L-valine (6).<smiles>C=CC(C)C(NC(C)=O)c1nccs1</smiles>

11<smiles>C=CC(=O)NC(C(N)=S)C(C)C</smiles>

10

Scheme 1. Retrosynthetic analysis of virenamide A (1) and D (4)

\section{EXPERIMENTAL PROCEDURE}

Melting points $(\mathrm{mp})$ are uncorrected and were measured on a microscopic melting point apparatus. The IR spectra were recorded on a Bruker Tensor $27 \mathrm{FT}$-IR spectrometer with a $\mathrm{KBr}$ disk. The ${ }^{1} \mathrm{H}$ NMR and ${ }^{13} \mathrm{C}$ NMR spectra were taken on a Bruker AV 300 or AV $500 \mathrm{MHz}$ and 75 or $125 \mathrm{MHz}$ spectrometer in $\mathrm{CDCl}_{3}$, chemical shift are given in part per million (ppm) relative to TMS as an internal standard. Mass spectra and High Resolution Mass spectra were performed on Agilent Q TOF 6520 mass spectrometer with electron spray ionization (ESI) as the ion source. Optical rotations were recorded using a sodium lamp with a Rudolph Autopol I Automatic Polarimeter with $1 \mathrm{dm}$ tube. (S)-tert-butyl 1-amino-3-methyl-1oxobutan-2-ylcarbamate (7) [9], (S)-tert-butyl 1-amino-3-methyl-1-thioxobutan-2-ylcarbamate (9) [10-12], (S)-2-methyl-1(thiazol-2-yl)propan-1-amine hydrochloride (12) [8], and (S)-2-((S)-2-(tert-butoxycarbonylamino)-3-phenylpropanamido)-3methylbutanoic acid (13) [15], were prepared following the literature procedures. 


\section{(S)-(-)-N-(tert-butoxycarbonyl)-1-(2-thiazolyl)-2-methylpropylamine (11)}

DIPEA (2.09 g, $16 \mathrm{mmol})$ was added to a solution of compoumd 9 (0.928g, $4 \mathrm{mmol}$ ) in anhydrous DME (16 $\mathrm{mL})$. Bromoacetaldehyde $10(1.48 \mathrm{~g}, 12 \mathrm{mmol})$ was added and the solution was stirred at $\mathrm{rt}$ for $14 \mathrm{~h}$. The mixture was evaporated in vacuo and the residue was partitioned between $\mathrm{H}_{2} \mathrm{O}(96 \mathrm{~mL})$ and $\mathrm{Et}_{2} \mathrm{O}(48 \mathrm{~mL})$. The aqueous layer was further extracted with $\mathrm{Et}_{2} \mathrm{O}(48 \mathrm{~mL})$ and the combined organic extracts were washed with brine $(24 \mathrm{~mL}), \mathrm{dried}\left(\mathrm{Na}_{2} \mathrm{SO}_{4}\right)$ and evaporated in vacuo. The residue was re-dissolved in anhydrous DME $(15 \mathrm{~mL})$ and cooled to $0{ }^{\circ} \mathrm{C}$. A solution of TFAA (1.34 g, $5.6 \mathrm{mmol})$ and dry Pyridine $(1.02 \mathrm{~g}, 12.8 \mathrm{mmol})$ in anhydrous DME $(4.5 \mathrm{~mL})$ was added and the solution was stirred at $0{ }^{\circ} \mathrm{C}$ for $0.5 \mathrm{~h}$. The reaction mixture was evaporated in vacuo. The residue was dissolved in $\mathrm{CHCl}_{3}(75 \mathrm{~mL})$, washed with $\mathrm{H}_{2} \mathrm{O}(40 \mathrm{~mL})$ and brine $(40 \mathrm{~mL})$. Evaporation of the solvent followed by purification on silica gel afforded colorless oil 11 (0.839 g, 82\%, ee 94.5\%). [a] ${ }_{D}^{20}-32.9^{\circ}$ (c 1.10, $\left.\mathrm{CHCl}_{3}\right)$; IR spectrum $\left(\mathrm{CHCl}_{3}\right) v_{\max } / \mathrm{cm}^{-1}: 3298(\mathrm{NH}), 1703$ $(\mathrm{C}=\mathrm{O}),{ }^{1} \mathrm{H}$ NMR spectrum $\left(300 \mathrm{MHz}, \mathrm{CDCl}_{3}\right) \delta 7.67(\mathrm{~d}, 1 \mathrm{H}, J 3.3 \mathrm{~Hz}$, thiazole $\mathrm{H}-1), 7.17(\mathrm{~d}, 1 \mathrm{H}, J 3.3 \mathrm{~Hz}$, thiazole $\mathrm{H}-2)$, 5.21 (br d, $1 \mathrm{H}, J 8.9 \mathrm{~Hz}, \mathrm{NH}), 4.84(\mathrm{dd}, 1 \mathrm{H}, J 5.5,8.9 \mathrm{~Hz}, \mathrm{CHNH}), 2.30-2.23\left(\mathrm{~m}, 1 \mathrm{H}, C H \mathrm{Me}_{2}\right), 1.38\left(b r \mathrm{~s}, 9 \mathrm{H}, 3 \mathrm{CH}_{3}\right), 0.90$ $\left(\mathrm{d}, 3 \mathrm{H}, J 6.8 \mathrm{~Hz}, \mathrm{CH}_{3}\right), 0.85\left(\mathrm{~d}, 3 \mathrm{H}, J 6.8 \mathrm{~Hz}, \mathrm{CH}_{3}\right)$. Spectral data of 11 were identical to those described in reference [8].

\section{N-(tert-butoxycarbonyl)-L-phenylalanyl-N-[(S)-(-)-1-(thiazole-2-yl)-2-methyl-propyl]-L-valinamide (14)}

Compound $13(0.262 \mathrm{~g}, 0.72 \mathrm{mmol})$ was dissolved in dry THF $(8 \mathrm{~mL})$ under nitrogen and cooled to $0{ }^{\circ} \mathrm{C}$. $\mathrm{N}$ Methylmorpholine $(0.219 \mathrm{~g}, 2.16 \mathrm{mmol})$ and iso-butyl chloroformate $(0.099 \mathrm{~g}, 0.72 \mathrm{mmol})$ were added sequentially to the solution and stirred for $50 \mathrm{~min}$. Compound $12(0.115 \mathrm{~g}, 0.60 \mathrm{mmol})$ in dry DMF $(2 \mathrm{~mL})$ was added in one portion, and the mixture was stirred for $1 \mathrm{~h}$. Water, brine, and EtOAc were added, and the layers were separated. The aqueous phase was further extracted with EtOAc. The combined EtOAc extracts were washed with water, dried $\left(\mathrm{Na}_{2} \mathrm{SO}_{4}\right)$, filtered, and evaporated. The residue was purified by column chromatography on silica gel to give colorless syrup $14(0.163 \mathrm{~g}, 54 \%$ yield). [a] ${ }_{D}^{25}-50.1$ (c $\left.0.90, \mathrm{CHCl}_{3}\right)$; IR spectrum $\left(\mathrm{CHCl}_{3}\right) v_{\max } / \mathrm{cm}^{-1}: 3342(\mathrm{NH}), 3275(\mathrm{NH}), 3030\left(\mathrm{CH}_{\text {arom. }}\right), 2962\left(\mathrm{CH}_{\text {aliph. }}\right)$, $1690(\mathrm{C}=\mathrm{O}), 1675(\mathrm{C}=\mathrm{O}), 1643(\mathrm{C}=\mathrm{O}) ;{ }^{1} \mathrm{H}$ NMR spectrum $\left(300 \mathrm{MHz}, \mathrm{CDCl}_{3}\right) \delta 7.85(1 \mathrm{H}, \mathrm{d}, J 8.4 \mathrm{~Hz}, \mathrm{NH}), 7.78(1 \mathrm{H}, \mathrm{d}, J$ 3.3 Hz, thiazole $\mathrm{H}-4), 7.16-7.27(5 \mathrm{H}, \mathrm{m}, \mathrm{Ar}-\mathrm{H}), 7.23(1 \mathrm{H}, \mathrm{d}, J 3.3 \mathrm{~Hz}$, thiazole H-5), $7.08(1 \mathrm{H}, \mathrm{brd}, J 8.4 \mathrm{~Hz}, \mathrm{NH}), 5.82(1 \mathrm{H}$, br d, J $7.2 \mathrm{~Hz}, N H B o c), 5.24(1 \mathrm{H}, \mathrm{dd}, J$ 6.9, $9.0 \mathrm{~Hz}, \mathrm{CH}), 4.52(2 \mathrm{H}, b r \mathrm{t}, J 8.1 \mathrm{~Hz}, 2 \mathrm{CH}), 2.96-3.11\left(2 \mathrm{H}, \mathrm{m}, \mathrm{CH}_{2} \mathrm{Ph}\right), 2.36-$ $2.46(1 \mathrm{H}, \mathrm{m}, \mathrm{CHMe}), 2.04-2.11(1 \mathrm{H}, \mathrm{m}, \mathrm{CHMe}), 1.36\left(9 \mathrm{H}, \mathrm{s}, 3 \mathrm{CH}_{3}\right), 0.91-0.96\left(6 \mathrm{H}, \mathrm{m}, 2 \mathrm{CH}_{3}\right), 0.84-0.87(6 \mathrm{H}, \mathrm{m}, 2 \mathrm{CH})$; ${ }^{13} \mathrm{C}$ NMR spectrum $\left(75 \mathrm{MHz}, \mathrm{CDCl}_{3}\right) \delta 171.9,170.9(\mathrm{C}=\mathrm{O}), 170.6$ (thiazole $\left.\mathrm{C}-3\right), 155.5(\mathrm{C}=\mathrm{O}), 142.7$ (thiazole $\left.\mathrm{C}-1\right), 136.7$, 129.2, 128.4, 126.7 (aromatic), 118.1 (thiazole C-2), 79.7, 58.8, 56.0, 55.7, 37.8, 33.3, 30.8, 28.2, 19.3, 19.1, 18.3, 18.0 (aliphatic); HRMS (ESI) calcd. for $\mathrm{C}_{26} \mathrm{H}_{38} \mathrm{~N}_{4} \mathrm{O}_{4} \mathrm{~S}$ [M+H]: 503.2687; found 503.2692.

\section{(S)-2-((S)-2-(bis(3-methylbut-2-enyl)amino)-3-phenylpropanamido)-3-methyl-N-((S)-2-methyl-1-(thiazol-2-yl)propyl)} butanamide (virenamide $A, 1$ )

To a solution of compound $15(47 \mathrm{mg}, 0.106 \mathrm{mmol})$ in $2.7 \mathrm{~mL}$ dry DMF, TBAI (8 $\mathrm{mg}, 0.0212 \mathrm{mmol})$, prenyl bromide $(66 \mathrm{mg}, 0.424 \mathrm{mmol})$ and $\mathrm{NaHCO}_{3}(54 \mathrm{mg}, 0.636 \mathrm{mmol})$ were added sequentially at $\mathrm{rt}$ and the mixture was stirred at $70{ }^{\circ} \mathrm{C}$ for $2 \mathrm{~h}$. The solution was cooled to rt. Water $(5 \mathrm{~mL})$, brine $(5 \mathrm{~mL})$, and EtOAc $(10 \mathrm{~mL})$ were added, and the EtOAc extracts were separated. The aqueous phase was further extracted with EtOAc $(10 \mathrm{~mL})$. The combined EtOAc extracts was washed with brine $(4 \mathrm{~mL})$, dried $\left(\mathrm{Na}_{2} \mathrm{SO}_{4}\right)$, filtered, and evaporated. The residue was purified by column chromatography on silica gel to give virenamide A 1 (52 mg, 91\% yield). [a] $]^{21}-35.5$ (c $\left.0.16, \mathrm{CHCl}_{3}\right)$. (lit. ${ }^{6}$ [a] $]_{\mathrm{D}}-34.1\left(\mathrm{c} 0.14, \mathrm{CHCl}_{3}\right) ; \mathrm{IR}$ $\left(\mathrm{CHCl}_{3}\right) v_{\max } / \mathrm{cm}^{-1}: 3405(\mathrm{NH}), 3318(\mathrm{NH}), 3026\left(\mathrm{CH}_{\text {arom. }}\right), 2964\left(\mathrm{CH}_{\text {aliph. }}\right), 2928\left(\mathrm{CH}_{\text {aliph. }}\right), 1647(\mathrm{C}=\mathrm{O}) ;{ }^{1} \mathrm{H}$ NMR spectrum $\left(300 \mathrm{MHz}, \mathrm{CDCl}_{3}\right) \delta 7.82(\mathrm{~d}, 1 \mathrm{H}, J 8.8 \mathrm{~Hz}, \mathrm{NH}), 7.68(\mathrm{~d}, 1 \mathrm{H}, J 3.3 \mathrm{~Hz}$, thiazole H-1), 7.16-7.25 (m, 5H, Ar-H), 7.21 (d, $1 \mathrm{H}, J$ $3.3 \mathrm{~Hz}$, thiazole H-2), $6.82(\mathrm{~d}, 1 \mathrm{H}, J 8.8 \mathrm{~Hz}, \mathrm{NH}), 5.19(\mathrm{dd}, 1 \mathrm{H}, J 5.4,8.8 \mathrm{~Hz}, \mathrm{CH}-4), 5.13(\mathrm{t}, 2 \mathrm{H}, J 6.7 \mathrm{~Hz},=\mathrm{CH}-21), 4.21$ (dd, $1 \mathrm{H}, J 6.7,8.8 \mathrm{~Hz}, \mathrm{CH}-9), 3.75$ (dd, $1 \mathrm{H}, J 6.3,6.5 \mathrm{~Hz}, \mathrm{CH}-14), 3.31$ (dd, $1 \mathrm{H}, J 6.6,14.2 \mathrm{~Hz}, \mathrm{CH}-15), 3.08$ (d, $4 \mathrm{H}, J 6.6$ $\mathrm{Hz}, 2 \mathrm{CH}_{2}-20$ ), 2.88 (dd, $1 \mathrm{H}, J 6.0,14.1 \mathrm{~Hz}, \mathrm{CH}-15$ ), 2.33 (dqq, $1 \mathrm{H}, J 5.7,6.2,6.3 \mathrm{~Hz}, \mathrm{CHMe}-5$ ), 2.27 (dqq, $1 \mathrm{H}, J 6.8,6.8$, $6.8 \mathrm{~Hz}, \mathrm{CHMe}-10), 1.69\left(\mathrm{~s}, 6 \mathrm{H}, 2 \mathrm{CH}_{3}-24\right), 1.55\left(\mathrm{~s}, 6 \mathrm{H}, 2 \mathrm{CH}_{3}-23\right), 0.95$ (d, 3H, J $\left.6.7 \mathrm{~Hz}, \mathrm{CH}_{3}-12\right), 0.94(\mathrm{~d}, 3 \mathrm{H}, J 6.8 \mathrm{~Hz}$, $\left.\mathrm{CH}_{3}-11\right), 0.86\left(\mathrm{~d}, 3 \mathrm{H}, J 6.3 \mathrm{~Hz}, \mathrm{CH}_{3}-7\right), 0.84\left(\mathrm{~d}, 3 \mathrm{H}, J 6.2 \mathrm{~Hz}, \mathrm{CH}_{3}-6\right) .{ }^{13} \mathrm{C}$ NMR spectrum $\left(125 \mathrm{MHz}, \mathrm{CDCl}_{3}\right) \delta 174.2,170.9$ $(\mathrm{C}=\mathrm{O}), 170.6$ (thiazole C-3), 142.5 (thiazole C-1), 140.9 (aromatic), 135.5 (C-22), 129.2, 128.3, 125.8 (aromatic), 122.0 (C21), 118.3 (thiazole C-2), 64.8, 58.7, 56.1, 48.2, 33.3, 31.0, 29.7, 25.8, 19.5, 19.1, 18.1, 17.9, 17.3 (aliphatic); MS m/z (\%): 539 (100), 471 (50), 431 (45); HRMS (ESI) calcd. for $\mathrm{C}_{31} \mathrm{H}_{46} \mathrm{~N}_{4} \mathrm{O}_{2} \mathrm{~S}$ [M+H]: 539.3414; found 539.3409.

\section{(S)-3-methyl-N-((S)-2-methyl-1-(thiazol-2-yl)propyl)-2-((S)-2-(3-methylbut-2-enylamino)-3-phenylpropanamido) butanamide (virenamide $D, 4)$}

To a solution of compound 15 (47 mg, $0.106 \mathrm{mmol})$ in $2.7 \mathrm{~mL}$ dry DMF, TBAl (4 mg, $0.0106 \mathrm{mmol})$, prenyl bromide $(33 \mathrm{mg}, 0.212 \mathrm{mmol})$ and $\mathrm{NaHCO}_{3}(36 \mathrm{mg}, 0.424 \mathrm{mmol})$ were added sequentially at $\mathrm{rt}$ and the mixture was stirred at $70{ }^{\circ} \mathrm{C}$ for $2 \mathrm{~h}$. The solution was cooled to rt. Water $(5 \mathrm{~mL})$, brine $(5 \mathrm{~mL})$, and EtOAc $(10 \mathrm{~mL})$ were added, and the EtOAc extracts were separated. The aqueous phase was further extracted with EtOAc (10 mL). The combined EtOAc extracts were washed with brine $(4 \mathrm{~mL})$, dried $\left(\mathrm{Na}_{2} \mathrm{SO}_{4}\right)$, filtered, and evaporated. The residue was purified by column chromatography on silica gel to give virenamide $\mathrm{D} 4(39 \mathrm{mg}, 79 \% \text { yield). [a] }]_{\mathrm{D}}^{21}-65.6$ (c $\left.0.25, \mathrm{CHCl}_{3}\right)$ (lit. ${ }^{7}[\mathrm{a}]_{\mathrm{D}}-65\left(\mathrm{c} 0.07, \mathrm{CHCl}_{3}\right) ; \mathrm{IR}$ $\left(\mathrm{CHCl}_{3}\right) v_{\max } / \mathrm{cm}^{-1}: 3409(\mathrm{NH}), 3310(\mathrm{NH}), 3019\left(\mathrm{CH}_{\text {arom. }}\right), 2963\left(\mathrm{CH}_{\text {aliph. }}\right), 2929\left(\mathrm{CH}_{\text {aliph. }}\right), 1644(\mathrm{C}=\mathrm{O}) ;{ }^{1} \mathrm{H}$ NMR spectrum $\left(300 \mathrm{MHz} \mathrm{CDCl}_{3}\right) \delta 7.96(\mathrm{~d}, 1 \mathrm{H}, J 9.1 \mathrm{~Hz}, \mathrm{NH}), 7.72(\mathrm{~d}, 1 \mathrm{H}, J 3.3 \mathrm{~Hz}$, thiazole H-1), 7.20-7.34 (m, 5H, Ar-H), $7.22(\mathrm{~d}, 1 \mathrm{H}, J$ 3.3 Hz, thiazole H-2), $7.09(\mathrm{~d}, 1 \mathrm{H}, J 8.8 \mathrm{~Hz}, \mathrm{NH}), 5.24(\mathrm{dd}, 1 \mathrm{H}, J 5.7,8.9 \mathrm{~Hz}, \mathrm{CH}-4), 4.98(b r \mathrm{t}, 1 \mathrm{H}, J 7.6 \mathrm{~Hz},=\mathrm{CH}-21), 4.28$ (dd, $1 \mathrm{H}, J 7.3,9.0 \mathrm{~Hz}, \mathrm{CH}-9$ ), 3.37 (dd, $1 \mathrm{H}, J 3.9,9.7 \mathrm{~Hz}, \mathrm{CH}-14), 3.25$ (dd, $1 \mathrm{H}, J$ 13.8, $3.9 \mathrm{~Hz}, \mathrm{CH}-15), 3.10$ (br dd, $1 \mathrm{H}, J$ 13.3, 7.6 Hz, CH-20), 2.98 (br dd, 1H, J 13.3, 7.6 Hz, CH-20), 2.69 (dd, 1H, J 13.8, $9.7 \mathrm{~Hz}, \mathrm{CH}-15), 2.37$ (dqq, 1H, J 5.5, 6.8, $6.8 \mathrm{~Hz}, \mathrm{CHMe}_{2}-5$ ), 2.22 (dqq, $\left.1 \mathrm{H}, \mathrm{J} 7.7,6.6,6.6 \mathrm{~Hz}, \mathrm{CHMe}-10\right), 1.63$ (s, 3H, $\left.\mathrm{CH}_{3}-24\right), 1.46$ (s, 3H, CH $\left.3-23\right), 1.40(b r$, $1 \mathrm{H}, \mathrm{NH}), 0.94\left(\mathrm{~d}, 3 \mathrm{H}, J 6.7 \mathrm{~Hz}, \mathrm{CH}_{3}-7\right), 0.92\left(\mathrm{~d}, 3 \mathrm{H}, J 6.7 \mathrm{~Hz}, \mathrm{CH}_{3}-6\right), 0.92\left(\mathrm{~d}, 3 \mathrm{H}, J 6.7 \mathrm{~Hz}, \mathrm{CH}_{3}-11\right), 0.89$ (d, 3H, J6.7 Hz, $\left.\mathrm{CH}_{3}-12\right) .{ }^{13} \mathrm{C}$ NMR spectrum $\left(75 \mathrm{MHz}, \mathrm{CDCl}_{3}\right) \delta 174.3,170.9(\mathrm{C}=\mathrm{O}), 170.6$ (thiazole $\left.\mathrm{C}-3\right), 142.6$ (thiazole $\left.\mathrm{C}-1\right), 137.4$ (aromatic), 135.5 (C-22), 129.1, 128.7, 126.9 (aromatic), 121.8 (C-21), 118.3 (thiazole C-2), 63.1, 58.6, 56.1, 46.0, 39.3, 
33.4, 30.1, 25.6, 19.5, 19.2, 18.1, 17.6, 17.6 (aliphatic); MS m/z (\%): 471 (100), 427 (45), 413 (40); HRMS (ESI) calcd. for $\mathrm{C}_{26} \mathrm{H}_{38} \mathrm{~N}_{4} \mathrm{O}_{2} \mathrm{~S}[\mathrm{M}+\mathrm{H}]: \mathrm{m} / \mathrm{z}$ 471.2788; found 471.2784 .

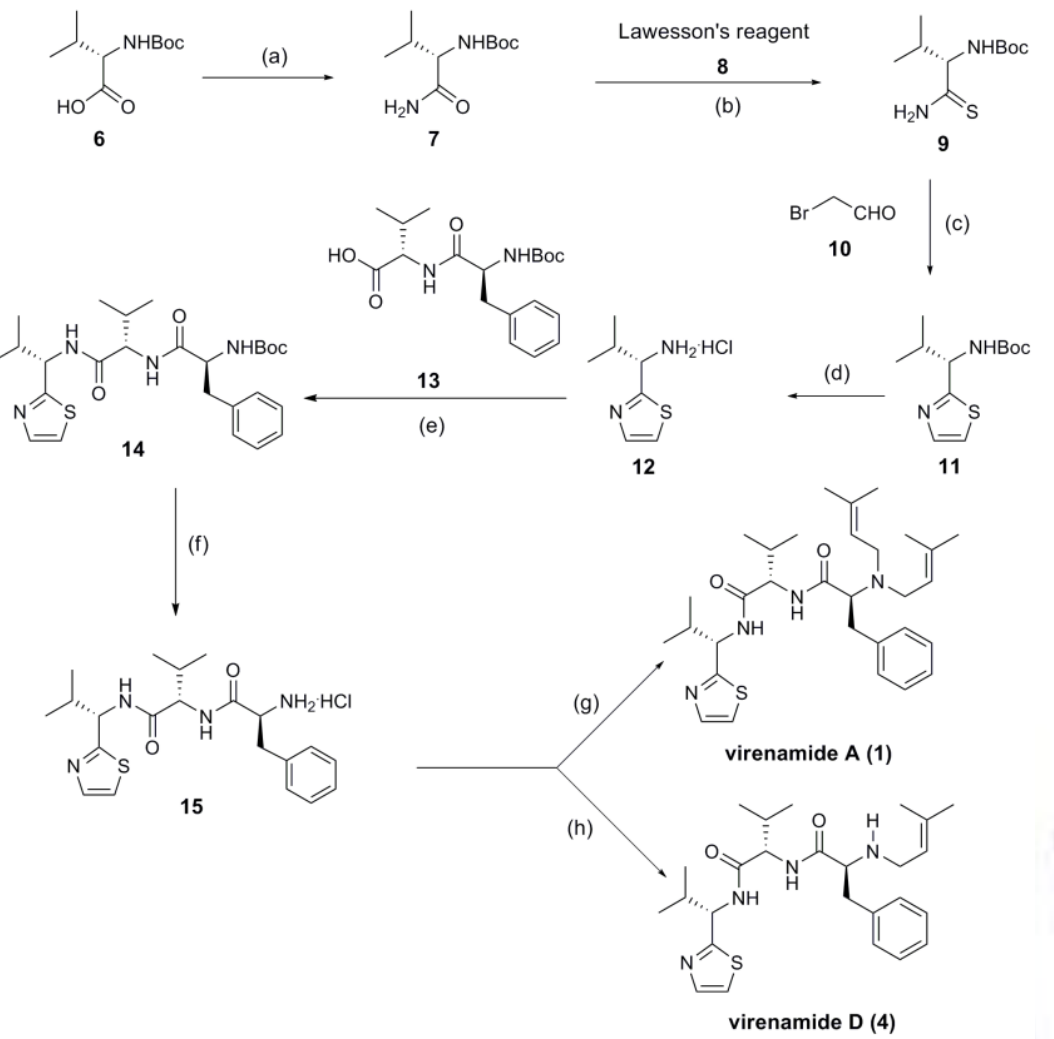

Scheme 2. The synthesis of Virenamides $A(1)$ and $D(4)$. Reagents and conditions: (a) CICOOEt, TEA, dry THF, $0{ }^{\circ} \mathrm{C}$, 1h; $25 \% \mathrm{NH}_{4} \mathrm{OH}$, r.t., $1 \mathrm{~h}, 94 \%$; (b) Lawesson's reagent 8, dry $\mathrm{CH}_{2} \mathrm{Cl}_{2}$, reflux, $16 \mathrm{~h}, 79 \%$; (c) (i) $\mathrm{BrCH}_{2} \mathrm{CHO}$, DIPEA, dry DME, r.t., $14 \mathrm{~h}$; (ii) TFAA, dry pyridine, dry DME, $0^{\circ} \mathrm{C}, 0.5 \mathrm{~h}, 82 \%$ in two steps; (d) Acetyl chloride, dry MeOH, r.t., $4 \mathrm{~h}$, quantitative; (e) CICOOBu-i, NMM, dry THF, $0{ }^{\circ} \mathrm{C}$, 1h, r.t., 1h, 54\%; (f) Acetyl chloride, dry MeOH, r.t., 4h, quantitative; (g) Prenyl bromide, DIPEA, TBAI, dry DMF, $70{ }^{\circ} \mathrm{C}, 2 \mathrm{~h}, 91 \%$; (h) Prenyl bromide, $\mathrm{NaHCO}_{3}$, TBAI, dry DMF, r.t., $5 \mathrm{~h}, 79 \%$.

\section{RESULTS AND DISCUSSION}

In the present work we report the first total synthesis of virenamides $A$ and $D$ based on $\mathrm{N}-($ tert-butoxycarbonyl)-Lphenylalanyl-N-[(S)-(-)-1-(thiazole-2-yl)-2-methyl-propyl]-L-valinamide (14), which was prepared from (S)-(-)-N-(tertbutoxycarbonyl)-1-(2-thiazolyl)-2-methylpropylamine (11) [13], as key intermediate. As illustrated in Scheme 1, the cyclization of thiamide 9 [9-12] with bromoacetaldehyde 10 to form thiazole is the key step for synthesis of Virenamides A and $D$ and is crucial as it is prone to epimerization at the a-stereogenic center. We optimized the reaction conditions for this conversion. As can be seen from Table 1, when bromoacetaldehyde 10 effected the reaction (Entries 1, 2, no base), the deprotection of Boc group of $\mathbf{1 1}$ was observed because of the acidic condition where the simultaneous release of $\mathrm{HBr}$ during the cyclization. Thus, we treated the cyclization reaction mixture with $\mathrm{Boc}_{2} \mathrm{O} / \mathrm{TEA}$ to get 11 in moderate yield, but $\mathrm{HBr}$ in the reaction mixture resulted in almost entirely racemization of the product [13]. Based on what the literature described [13], we tried several inorganic bases and organic bases to form thiazoline intermediate, which was used for next step without purification. Dehydration of thiazoline intermediate afforded 11 in different yields and ee values. Although inorganic base could give high yield in general (Entries 4,5), it was found that organic base yield much better ee value (Entries 7-9). DIPEA was proved to be the best acid trapper, which gave a yield of $82 \%$ with $94.5 \%$ ee (Entry 7 ) according to chiral-HPLC analysis [14].

Having synthesized the key intermediate 11, the next step was to prepare intermediate 14. We should prepare dipeptide 13 firstly, which was through a two-step sequence. Boc-(L)-Phenylalanine was reacted with L-valine methyl ester to give dipeptide ester in 95\% yield, which was saponificated with $1 \mathrm{M} \mathrm{NaOH/THF}$ to give dipeptide 13 [15] in $94 \%$ yield. Then the synthesis of $\mathbf{1 4}$ was achieved in two steps including removal of Boc group from $\mathbf{1 1}$ to provide amine hydrochloride 12 [8], Coupling of 12 with dipeptide 13 with CICOOBu-i/NMM to give tripeptide 14 in 54\% yield [16]. Likewise, removal of $\mathrm{Boc}$ group from 14 with $\mathrm{AcCl}$ in $\mathrm{MeOH}$ smoothly provided amine hydrochloride 15 in almost quantitative yield, which was used for next step without further purification.

Finally, double alkylation of amine 15 with 4 equiv prenyl bromide in DMF at $70 \stackrel{\circ}{ } \mathrm{C}$ for $2 \mathrm{~h}$ afforded virenamide $\mathrm{A}(\mathbf{1})$ in $91 \%$ yield as a colorless oil ([a $]_{D}^{25}-35.5, \mathrm{c} 0.16$ in $\mathrm{CHCl}_{3}$ ), while mono-alkylation of 15 with 2 equiv prenyl bromide in DMF at room temperature for $5 \mathrm{~h}$ smoothly furnished virenamide $D(4)$ in $79 \%$ yield as a colorless oil $\left([\alpha]_{D}{ }^{21}-65.6, c 0.25\right.$ in $\mathrm{CHCl}_{3}$ ). 
The structures of compound $\mathbf{1}$ and $\mathbf{4}$ were determined from spectroscopic as well as optical rotation analytical data, which were consistent with those described for the ntatural products [6-7]. The ${ }^{1} \mathrm{H}$ NMR spectrum of compound 1 revealed a double signal at $\delta 3.08 \mathrm{ppm}(\mathrm{J} 6.6 \mathrm{~Hz})$ due to $=\mathrm{CH}$ protons, a triple signal at $\delta 5.13 \mathrm{ppm}(\mathrm{J} 6.7 \mathrm{~Hz})$ due to $\mathrm{CH}_{2}$ protons, two single signals at $\delta 1.55$ and $\delta 1.69$ due to $\mathrm{C} 22$. The high resolution mass spectrum of compound 1 showed [M+H] ${ }^{+}$at 539.3409 which is coincident with calculated $[\mathrm{M}+\mathrm{H}]^{+}(539.3414)$ as the molecular formula $\mathrm{C}_{31} \mathrm{H}_{46} \mathrm{~N}_{4} \mathrm{O}_{2} \mathrm{~S}$. While, the ${ }^{1} \mathrm{H}$ NMR spectrum of compound 4 showed a dd signal at $\delta 3.10$ and $2.98 \mathrm{ppm}(J 13.3,7.6 \mathrm{~Hz})$ due to $=\mathrm{CH}$ molecular formula , a broad triple signal at $\delta 4.98 \mathrm{ppm}(J 7.6 \mathrm{~Hz})$ due to $\mathrm{CH}_{2}$ protons, two single signals at $\delta 1.46$ and $\delta 1.63$ due to $\mathrm{C} 22$. The high resolution mass spectrum of compound 4 showed $[\mathrm{M}+\mathrm{H}]^{+}$at 471.2784 which is coincident with calculated $[\mathrm{M}+\mathrm{H}]^{+}$ (471.2788) as the molecular formula $\mathrm{C}_{26} \mathrm{H}_{38} \mathrm{~N}_{4} \mathrm{O}_{2} \mathrm{~S}$. Analytical data for new compound and copies of ${ }^{1} \mathrm{H} \mathrm{NMR}$ and ${ }^{13} \mathrm{C}$ NMR spectra can be found in supporting information.

Table 1. Optimization of reaction conditions ${ }^{a}$

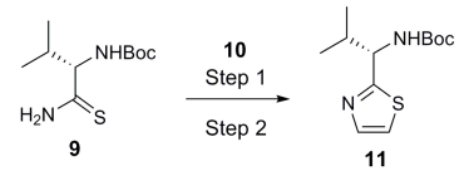

\begin{tabular}{|c|c|c|c|c|c|c|c|c|}
\hline \multicolumn{5}{|c|}{ Step 1} & \multicolumn{4}{|c|}{ Step 2} \\
\hline Entry & $\begin{array}{r}\text { Mol. ratio } \\
\text { (9:10:Base) }\end{array}$ & Solvent & $\mathbf{T}$ & Base & $\mathbf{T}$ & Reagents & $\begin{array}{l}\text { Yield } \\
(\%)^{c}\end{array}$ & $\begin{array}{c}e e \\
(\%)^{b}\end{array}$ \\
\hline 1 & $1: 1.1$ & Dioxane & r.t. & & r.t. & $(\mathrm{Boc})_{2} \mathrm{O}(1 \mathrm{eq})$, TEA $(1.1 \mathrm{eq})$ & 68 & 8 \\
\hline 2 & $1: 1.1$ & DME & r.t. & & r.t. & $(\mathrm{Boc})_{2} \mathrm{O}(1 \mathrm{eq})$, TEA $(1.1 \mathrm{eq})$ & 67 & 6.5 \\
\hline 3 & $1: 3: 4$ & DME & r.t. & $\mathrm{KHCO}_{3}$ & $0^{\circ} \mathrm{C}$ & TFAA (1.4 eq), Pyr (3.2 eq) & 76 & 66 \\
\hline 4 & $1: 3: 4$ & DME & $0^{\circ} \mathrm{C}$ & $\mathrm{KHCO}_{3}$ & $0^{\circ} \mathrm{C}$ & TFAA (1.4 eq), Pyr (3.2 eq) & $80^{4}$ & 61 \\
\hline 5 & $1: 3: 4$ & DME & r.t. & $\mathrm{NaHCO}_{3}$ & $0^{\circ} \mathrm{C}$ & TFAA (1.8 eq), Pyr (4.1 eq) & 82 & 70 \\
\hline 6 & $1: 3: 3$ & DME & r.t. & $\mathrm{K}_{2} \mathrm{CO}_{3}$ & $0^{\circ} \mathrm{C}$ & TFAA (1.4 eq), Pyr (3.2 eq) & 69 & 86 \\
\hline 7 & $1: 3: 4$ & DME & r.t. & DIPEA & $0^{\circ} \mathrm{C}$ & TFAA (1.4 eq), Pyr (3.2 eq) & 82 & 94.5 \\
\hline 8 & $1: 3: 4$ & DME & r.t. & TEA & $0^{\circ} \mathrm{C}$ & TFAA (1.4 eq), Pyr (3.2 eq) & 59 & 93 \\
\hline 9 & $1: 7: 8$ & DME & r.t. & NMM & $0^{\circ} \mathrm{C}$ & TFAA (1.1 eq), Pyr (2.6 eq) & $62^{\mathrm{e}}$ & 76 \\
\hline
\end{tabular}

${ }^{b}$ The ee values were calculated according to reference 8 (entries 3-6, 8, 9) or determined by chiral-HPLC (entries 2,7$)$.

${ }^{c}$ Isolated yields after flash column chromatography.

d The starting material was completely consumed after $36 \mathrm{~h}$.

e The starting material was not completely consumed after $36 \mathrm{~h}$.

\section{CONCLUSIONS}

In summary, we have developed a very concise route for the first total syntheses of virenamide $A$ and $D$ starting from BocL-valine in 7 -steps (overall yields: $26 \%$ for virenamide A; $22 \%$ for virenamide D). Syntheses of these natural products and their derivatives in large scale could be realized by this route, which facilitates further biological experiments. Studies towards the structure modifications of these natural products for further pharmacological investigation are ongoing.

\section{ACKNOWLEDGMENTS}

This work was financially supported by the National High Technology Research and Development Program of China (863 Program, No. 2013AA031901), National High Technology Research and Development Program of China (863 Program, No. 2012AA02A701) and Program for Changjiang Scholars and Innovative Research Team in University (Grant No. IRT1066).

\section{SUPPLEMENTARY DATA}

Supplementary data associated with this article can be found, in the online version, at http://

\section{REFERENCES}

[1] Faulkner, D. J. (1999), "Marine natural products", Nat. Prod. Rep., 16, 155-198

[2] (a) Fusetanl, N. and Matsunaga, S. (1993), "Bioactive sponge peptides", Chem. Rev., 93, 1793; (b) Delgado, O., Müller, H. M. and Bach, T. (2008), "Concise total synthesis of the thiazolyl peptide antibiotic GE2270 A", Chem. Eur. J., 14, 2322-2339; (c) Ranjitha, J., Himaja, M. and Mali, S. V. (2010), "Anticancer activity of thiazole-incorporated synthetic wainunuamide", Asian J. Chem., 22, 7655-7660; (d) Diness, F., Nielsen, D. S. and Fairlie, D. P. (2011), "Synthesis of the thiazole-thiazoline tragment of largazole analogues", J. Org. Chem., 76, 9845-9851.

[3] Wipf, P. (1995), "Synthetic studies of biologically active marine cyclopeptides", Chem. Rev., 95, 2115-2134. 
[4] Taori, K., Paul, V. J. and Luesch, H. (2008), "Structure and activity of largazole, a potent antiproliferative agent from the floridian marine cyanobacterium Symploca sp.", J. Am. Chem. Soc., 130, 13506-13506.

[5] Pettit, G. R., Kamano, Y. and Bontems, R. J. (1987), "The isolation and structure of a remarkable marine animal antineoplastic constituent: dolastatin 10", J. Am. Chem. Soc., 109, 6883-6885.

[6] Carroll, A. R., Feng, Y. and Bowden, B. F. (1996), "Studies of australian ascidians. 5. Virenamides A-C, new cytotoxic linear peptides from the colonial didemnid ascidian Diplosoma virens", J. Org. Chem., 61, 4059-4061; Professor Tony Carroll stated that the optical rotations for all three virenamides were large and the real optical rotation of virenamide $\mathrm{A}$ is $34.1^{\circ}$ and that typographical errors have occurred in the manuscript.

[7] Feng, Y. J. and Bowden, B. F. (1997), "Studies of australian ascidians, VI. Virenamides D and E, linear peptides from the colonial didemnid ascidian Diplosoma virens", Aust. J. Chem., 50, 337-339.

[8] Moody, C. J. and Hunt, J. C. A. (1999), "Synthesis of virenamide B, a cytotoxic thiazole-containing peptide", J. Org. Chem., 64, 8715-8717.

[9] Bagley, M. C., Buck, R. T., Hind, S. L. and Moody, C. J. (1998), "Synthesis of functionalised oxazoles and bisoxazoles", J. Chem. Soc., Perkin Trans. 1, 591-600.

[10] Lecher, H. Z., Greenwood, R. A., Whitehouse, K. C. and Chao, T. (1956), The phosphonation of aromatic compounds with phosphorus pentasulfide, J. Am. Chem. Soc., 78, 5018-5022.

[11] Sureshbabu, V. V., Naik, S. A. and Nagendra, G. (2009), "Synthesis of Boc-amino tetrazoles derived from a-amino acids", Synth. Commun., 39, 395-406.

[12] Tavecchia, P., Gentili, P. and Kurz, M. (1995), "Degradation studies of antibiotic MDL 62,879 (GE2270A) and revision of the structure", Tetrahedron, 51, 4867-4869.

[13] (a) Müller, H. M., Delgado, O. and Bach, T. (2007), "Total synthesis of the thiazolyl peptide GE2270A", Angew. Chem. Int. Ed., 46, 4771-4774; (b) Bredenkamp, M. W., Holzapfel, C. W. and Van Zyl, W. J. (1990), "The chiral synthesis of thiazole amino acid enantiomers", Synth. Commun., 20, 2235-2249; (c) Aguilar, E. and Meyers, A. I. (1994), "Reinvestigation of a modified Hantzsch thiazole synthesis", Tetrahedron Lett., 35, 2473-2476; (d) Merritt, E. A. and Bagley, M. C. (2007), "Holzapfel-Meyers-Nicolaou modification of the Hantzsch thiazole synthesis", Synthesis, 35353541; (e) Hamada, Y., Hayashi, K. and Shioiri, T. (1991), "Efficient stereoselective synthesis of dolastatin 10, an antineoplastic peptide from a sea hare", Tetrahedron Lett., 32, 931-934.

[14] The ee value of $\mathbf{1 1}$ (entries 2, 7 in table 1) were determined by chiral-HPLC. For the spectra of them, see supporting information.

[15] (a) Ray, S., Drew, M. G. B. and Banerjee, A. (2006), "The role of terminal tyrosine residues in the formation of tripeptide nanotubes: a crystallographic insight", Tetrahedron, 62, 7274-7283; (b) Fu, Y. Q., Xu, B., Zou, X., Ma, C., Yang, X., Mou, K., Fu, G., Lü, Y. and Xu, P. (2007), "Design and synthesis of a novel class of furan-based molecules as potential 20 S proteasome inhibitors", Bioorg. Med. Chem. Lett., 17, 1102-1106.

[16] Chen, Z. Y. and Ye, T. (2006), "The first total synthesis of aeruginosamide", New J. Chem., 30, 518-520. 